\title{
Servant leadership as part of spiritual formation of theological students in contextualisation of 21st century theological training
}

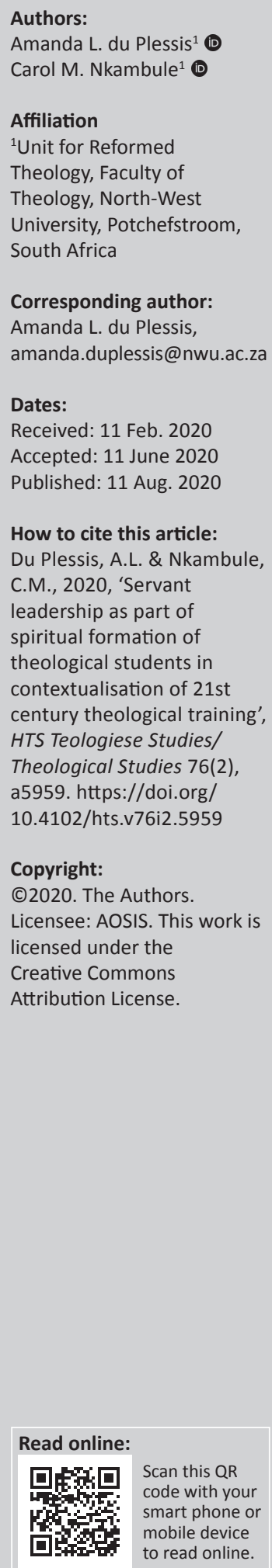

\begin{abstract}
The theory of servant leadership with its key concepts of servanthood and leadership has emerged during the last few decades. A person who has a heart for people and serves them whilst leading them practices servant leadership. Servant leaders are not motivated by attaining higher positions but by serving people. Leaders call people to follow a set vision. In the church, that vision ought to be a God vision, premised on the Word of God. Leaders in the church should lead people according to the guidance of the Bible and inspiration from God. He is the one who calls people, gives them an assignment and will require an account from them. The church has been in the spotlight in recent times because of the conduct of their leaders, who are the pastors assigned with the task of leading believers. Understanding the principles of servant leadership can contribute to spiritual formation of theological students in contextualisation of 21st century theological training. The article begins with a reflection on the findings of an empirical study, followed by a short view on the servant leadership of Moses, David, Paul and Jesus Christ. Thereafter, the article focuses on servant leadership characteristics and competencies or skills according to contemporary scholars, and the article concludes with a proposed model for servant leadership as part of spiritual formation of theological students.

Contribution: Although the article is context specific to the Faculty of Theology, Mahikeng campus, the principles of servant leadership can contribute to the spiritual formation of all theological students and is especially relevant to the discourse of contextualised 21st century theological training.
\end{abstract}

Keywords: Calling; Leadership; Servanthood; Spiritual formation; Theological training.

\section{Introduction}

This article is written as part of a project, Theological Education at the North-West University for the 21st Century South Africa and therefore, it is context-specific to the theological education at the Mahikeng campus of the North-West University. Currently, the B.Th. in Christian Ministry is presented as a programme consecutively for the past 12 years. Almost $80 \%$ of the students who enroll for this programme at the Mahikeng campus are adults who are already pastoring a church but lack formal theological training. Apart from the opportunity to receive formal theological training, the disadvantage is that the curriculum of the B.Th. has been built on predominantly cognitive training, whilst experiential and practical trainings have (still) been regularly overlooked. Because of the complex and interconnected context of South Africa, where students originate from different cultural backgrounds and frames of reference, the authors believe contextualisation of the curriculum content is unavoidable.

The goal of this project is to rethink theological training at the North-West University (NWU) for the 21st century South Africa and in the process, a 'federal-structured' (inter-denominational) Faculty of Theology is envisaged. The faculty expanded its academic offer with a range of Higher Certificate and Diploma qualification types. Maximising its utilisation of the Higher Education Qualifications Sub-Framework (HEQSF), a golden opportunity is created to accommodate a range of ecclesiastical requirements and preferences within the domain of accessible university education.

With this article, the authors participate in the project with the specific aim to focus on the spiritual formation of students. Theological education should be a life-creating process and

Note: This article is published in the section Practical Theology of the Society for Practical Theology in South Africa. 
experience. By broadening and deepening the students' spiritual formation, their education could have a life-long effect once they minister and live meaningfully in communities. The research question is what the principles ${ }^{1}$ of servant-leadership are and what servant leader characteristics $^{2}$ need to be developed to train servant leaders for the (South) African context to become effective and obedient servants of God and noble leaders of the people of God in the Christian faith paradigm.

The church in South Africa is constantly dealing with turmoil stemming from internal issues and this calls for a reflection on the above question. Regretfully, the very people currently at the helm of some churches are the cause of the unrest. Some of the issues include abuse of authority by pastors over congregants where for example, a church leader made the congregants to drink petrol, another made them to eat grass and another one sprayed congregants with insecticide (Mokhoathi \& Rembe 2017:2). Some of the issues are noncompliance to laws and regulations, soliciting money from congregants for blessings, governance issues and bad financial management (CRL Commission 2016:25). The relationship between some church leaders and their followers can even be called 'toxic' as it involves manipulation and mistreatment, which is tolerated and even preferred (LipmanBlumen 2005:18-19). Wealth, prestige and a huge following characterise some of the mega-churches today, and some pastors are highly elevated with bodyguards, a fleet of cars, numerous attendance and grand entrances into places of worship. Some members hold a pastor in high esteem, some even to the extreme of bordering on idolatry.

An attempt will be made to answer the research question using the servant leadership theory as part of spiritual formation of theological students, which has emerged over the last few decades. The theory presents two concepts in a continuum, namely leadership and servanthood. If these two concepts are defined individually, they could be understood wrongly and seem to be in conflict with each other. A leader is known to be prominent, on 'top' and one who influences other people, whilst a servant is generally known to carry out instructions and to be subservient to a leader. Yet, the servant leadership concept consolidates these ideas into one positive form of leadership. It presents a servant whose act of leadership is reflected in the function of a servant, not in the change or development of a leader becoming a servant. The most prominent Biblical examples of servant leaders include Moses, David, Paul and Jesus Christ. Church leaders are called to serve God and the people by leading the congregation.

In an attempt to reach the aim of attending servant leadership as part of spiritual formation of students, the article begins by reflecting on the results of an empirical research. The mixedmethod empirical study was carried out to determine the

1.A fundamental truth or proposition that serves as the foundation for a system or belief or behaviour or for a chain of reasoning.

2.A characteristic is a broad term for what is a distinctive or typical feature (or an important aspect) of someone or something. existential challenges South African pastors are facing that have an effect on their leadership. The findings of the empirical study were coded according to certain themes with the aim to highlight typical characteristics of the servant leader. Thereafter, modern theories on servant leadership will be investigated and servant leadership principles that are congruent with biblical principles will be identified. Using these leadership principles, the article concludes by proposing a servant leadership model that could be included in the curriculum of theological training as part of the spiritual formation of students. In this way, a contribution could be made to contextualising theological training in South Africa.

\section{Ethical considerations}

As part of the study, a mixed-method empirical research was carried out and ethical approval to conduct the study was obtained from the North-West University (reference no. NWU - 00580-17-A6), Faculty of Theology, Research Ethical Committee, North-West University.

\section{Results of empirical research Sampling}

The study covered pastors from 15 pre-selected churches of various denominations and a balanced age group in Mpumalanga, Limpopo and Gauteng. They participated in the qualitative research conducted through semi-structured interviews. A quantitative survey then followed with some church members from each of the participating churches. The denomination category of the 15 pre-selected churches varied with the inclusion of seven charismatic churches, three evangelical churches, two pentecostal churches, two independent churches and one mainline church. The longest serving pastor has 36 years in ministry and eight pastors have served less than 10 years. Ten of the 15 pastors have formal training qualifications in the form of a diploma, degree or certificate, three have postgraduate qualification and two do not have any formal training. The membership total of the pre-selected churches varied, $33 \%$ can be indicated as large (more than 800 members), $40 \%$ as medium (between 200 and 800 members) and $27 \%$ small (less than 200 members). One of these churches is a mega church with more than 40000 members.

\section{Data collection}

A total of 15 pastors were interviewed and 333 church members participated in the survey. The type of data was determined by the focus themes will provide information regarding leadership types, their leadership styles, their characteristics and the way they govern their specific congregations. The data collection started with the qualitative part with the pastors, followed by the compilation of the questionnaire for the execution of the survey with the church members. The results of the interviews were compared with the results of the survey, and both the qualitative and quantitative results were compared with how Jesus Christ demonstrated servant leadership. 


\section{Data analysis}

The data were coded according to 13 different themes, namely motivation, governance, vision and mission, leadership style and character, servant leadership, succession plan, church services, recognition of the role of the Holy Spirit, finances, pastoral care, conflict management, community engagement, commitment and future planning. Because of the compact version of an article, ${ }^{3}$ only relevant remarks of the findings will be given. As part of the data analysis, the findings were compared with the servant leadership style as portrayed by Jesus Christ recorded in the gospels.

Motivation: The motive for going into ministry was looked at. Without pointing to a specific event, most pastors were motivated by a calling. Pastors' motivation for ministry came from a calling identified mostly through inner voice and dreams, fewer had distinct audible voice and recommendation from others, whilst one had no calling but an opportunity to study through a bursary offered. Jesus' call was revealed before conception, and confirmed to Him and others at baptismal with an audible voice from heaven. Jesus subsequently called His disciples publicly and appointed them as apostles.

Governance: The participating churches had various structures of governance, including leadership or advisory boards, apostolic leadership structures, elders, deacons and pastors. This aspect was in line with how Jesus shared governance by appointing 12 disciples, and still had three who were closer to Him than the others.

Vision and mission: Almost all the pastors have certain visions and missions for their church that are shared with members, though some members had no interest in taking responsibilities towards that vision. Jesus taught the disciples about the vision of the kingdom of heaven, mostly through parables, and they continued with that vision even after $\mathrm{He}$ departed from the earth.

Leadership style and character: Most pastors were using a combination of various leadership styles, and some offered no reflection on their leadership styles, indicating a lack of awareness of leadership styles. Some pastors struggled to describe their characters, whilst some indicated honesty, integrity, high ethics and sincerity. It was difficult for some of the pastors to identify their character flaws, though a few mentioned that they were impatient and short-tempered. Jesus was a servant leader who shared His vision, served others even doing menial tasks, empowered His followers and took care of their needs above His own, acknowledging faithfulness. Jesus never coerced or forced anyone to follow Him and He gave people a choice.

Servant leadership: Some pastors consciously sought to emulate Jesus' servant leadership style, striving to attain that level. Comprehension of the concept of servant leadership 3.The empirical study was also part of a PhD study and the full process and results can be viewed in Nkambule (2019). was a challenge for some of the pastors. The definition by some included prioritising people, serving, meekness and being dedicated.

Some pastors were able to identify spiritual gifts in their members and a few pastors have training programmes for those whom they believed had gifts. Three out of the 15 pastors reported that they supported those who had gifts in establishing churches by covering their costs and availing some members to support with church establishment. Mostly, pastors were the main preachers, assistant pastors or elders led services other than Sunday services. Jesus even rebuked His disciples who aspired for prominence and called them to servanthood.

Shared leadership: Shared leadership was still lacking in most of these churches, as the focus was on the pastor as the main preacher. This is in contrast with what Jesus taught the disciples and sent them out on their own. The essence of the concept of shared leadership is that there are gifts that should emerge when people are given opportunities to serve.

Succession plan: Most of the churches did not have a succession plan and a few mentioned that they are still working on it. Flowing from shared leadership, a proper succession plan can give the vision a chance of continuity. Jesus prepared the 12 , then the 70 , and the number grew.

Church services: The pastors are committed to the great commission; however, many of them were concerned about the poor attendance of midweek services that points to the low commitment of some members. During the survey, the members corroborated this as well and justified it with life pressures. In the ministry of Jesus, multitudes followed Him and at times, they stayed with Him for days. The necessity for commitment by church members was identified as a potential theme for further study.

Recognition of the role of the Holy Spirit: The gifts of the Holy Spirit operated mostly through the pastors and leaders. There was limited evidence of members having and or using the gifts of the Holy Spirit. Most pastors refrained from using items like oil and water when praying for people, saying that people become dependent on the symbols instead of depending on God. They were also wary of being viewed in a negative light by the general public. Those who used oil and water reported using it occasionally when prompted or for a special event, for instance, ordination. The Holy Spirit came on Jesus whilst He was baptised before He embarked on His ministry.

Finances: The subject of finances addresses accountability and stewardship. Most pastors did not inform their members about their finances; however, the records were available for members on request. Jesus taught about stewardship and against wasting resources, even though Judas whom Jesus knew was dealing with the finances in a dishonest way held the group's finances. He taught on being responsible for what has been put under one's care. 
Pastoral care: Most of the pastors provided pastoral care through calls, prayers and counselling, and the members corroborated the findings during the survey. The only challenge was found in the bigger or mega churches where the members would generally not have access to the pastor, but cell group system was used. Jesus went to dine with the people, even the sinners and the Pharisees. He demonstrated care for the people, by healing the sick and feeding the hungry.

Conflict management: The study found that pastors were prepared to handle conflicts even to the point of apologising when they are at fault. The responses from members did not fully agree with the pastors, with a 55\% satisfaction level. Jesus taught the disciples how to handle conflict, mostly taking the position of peace seeking.

Community engagement: The impact of the church in communities includes social development, involvement in political structures and an overall positive influence. Though Jesus did respond to some of the social needs of the people, it was never His focus. He was more interested in their spiritual well-being.

Commitment and future planning: Despite having been hurt in their ministries, most pastors indicated their commitment to the call of God. Some indicated that if they knew the cost of ministry, they probably would not have accepted, but remained committed anyhow. The members were mostly committed to remain in the church, some wishing for better administration, spiritual growth and better infrastructure. Jesus was committed to His ministry to the point of death.

\section{Principles deducted from the empirical study}

Time is the best indicator of whether a person's actions have impact or not (Nkambule 2019:212). This is relevant to the impact that the ministry of Jesus Christ has on the world. The impact of the disciples was felt to the extent that they were said to be turning the world upside down (Ac 17:6).

Conducting the empirical study gave the authors insight into the life, accomplishments and struggles that pastors experience in their ministry, as well as the expectations church members have from their pastors. Although the results of the empirical study were mostly positive and the pastors' impact in their respective contexts are visible, the authors concluded that a deeper knowledge about a theme such as servant leadership as part of the spiritual formation of a pastor will give them the necessary skills to overcome the struggles and challenges many of them experience in their ministry.

\section{Servant leadership training as part of spiritual formation of theological students}

When theological students are trained to understand the principles inherent in servant leadership as part of their spiritual formation, they will have a greater chance of experience in their ministry as fulfilling. An awareness of the personal characteristics of a servant leader will have a positive effect on their resilience when dealing with difficult challenges. Not all theological students are natural leaders, but with fundamental knowledge about the principles of servant leadership and the characteristics of servant leaders, they will be able to apply the principles to continuously develop their competencies and skills.

The rest of the article will, therefore, be explorative in nature on the theme of including servant leadership training as part of the spiritual formation of theological students. Theory formation is necessary as a foundation for the inclusion of (new) content in a curriculum. Consequently, the formation will start with a short view on the servant leadership of Moses, David, Paul and Jesus Christ. Thereafter, the focus will be on servant leadership characteristics and competencies or skills according to contemporary scholars and the article will conclude with a proposed model for servant leadership as part of spiritual formation of theological students.

\section{Servant leadership in the Bible}

The Christian church ought to be founded on principles espoused in the Bible. Various biblical leaders provide important lessons, including the lessons Jesus Himself offered. The one who leads ought to be like a shepherd who goes before the sheep, finds good pasture and water, and takes the sheep to safe places known to him. Because the flock is close to the heart of the shepherd, caring for their wellbeing is his main concern. Jesus taught the disciples the basic principles of servanthood when they were arguing about who should be prominent in the kingdom, saying to them, 'If anyone desires to be first, he shall be last of all and servant of all' (Mk 9:35).

Several leaders in the Bible portray servant leadership, for instance Moses, David, Paul and Jesus Christ. The leadership of each of them will now be investigated to identify principles of servant leadership and characteristics of the servant leader.

\section{Moses}

Moses rose to a leadership position in the congregation of Israel by standing up for the Israelites, even at the expense of losing his place in Pharaoh's palace. God revealed his calling through the burning bush incident, and empowered him with authority and power to do miracles. Through courage, power and authority, Moses and Aaron went to Egypt and did signs and wonders that eventually persuaded Pharaoh to release the people. As they journeyed in the desert, Moses listened to the instructions of God and communicated that to the people. Moses initially took responsibility for all cases, and because he could not attend to everyone on time, the people became disruptive (Constable 2017a:109). Jethro advised Moses to delegate functions to leaders in the congregation of Israel. Moses listened and took Jethro's advice (Ex 18). In this 
incident, Moses demonstrated listening skills and subsequently, shared leadership and empowerment. A servant leader listens and considers advice and views from others before making a decision. Moses received instructions for building the tabernacle, conceptualised it and instructed the people to do the work. He also called for a contribution, and when it was enough, he stopped the people from giving more than required, which was an act of integrity in managing finances and resources (Ex 36:6-7). Moses pleaded to God for the people, demonstrating empathy and compassion, though they complained, murmured and disobeyed (Ex 32:10). When God offered Moses the Promised Land instead of the people, Moses arose as a servant leader and put the people first. He prayed to God on their behalf (Ben-Hur \& Jonsen 2012:967). Moses listened attentively and was guided by God throughout the journey, from the burning bush, and all he had to tell Pharaoh with each plague, and getting the 10 Commandments (Hays 2012:6). Having listened to God for many years, Moses failed to obey an instruction once and missed the opportunity of going to the Promised Land (Nm 20:7-12, 27:12-17). Moses commissioned Joshua to lead Israel after him, empowering him with authority (Kislev 2009:429). Indicative of his selflessness, Moses did not select a person he favoured, but asked God to choose a man to take over his leadership role, and he did not choose his own sons (Nm 27:15-17).

Principles of servant leadership that can be identified from the above discussion of the leadership of Moses are the following: God Himself calls people - sinful and frequently unwilling people - as servant leaders in His work, not for their own benefit but to serve others. On the one hand, $\mathrm{He}$ endows them with leadership qualities, prepares them, supports them and equips them in such a way that they can act with authority and wisdom. God expects them to be patient with their followers, to have compassion for them, to learn to deal with criticism and to obey and trust Him. He expects leaders to follow his religious prescriptions and rites, thereby showing and promising visually and tangibly that His people belong to Him and that He will free them from bondage, physically and spiritually. Servant leadership characteristics are for instance obedience to God, trust in God, wisdom, courage, authority, integrity compassion, empathy, patience, dealing with criticism, selflessness, perseverance, managerial qualities and foresight.

\section{David}

The concept of servant leadership is not easily associated with kings given their position, status and corresponding service they receive from their subjects and servants. David claimed his leadership position through his victory over Goliath, a selfless act that saw him becoming a leader in the army (Serrano 2015:38). Through this one act, David demonstrated love, humility, philanthropy, vision, belief, service and empowerment (Serrano 2015:39). It took courage in David to fight and defeat an enemy who had the benefit of experience, armament and was older than him (1 Sm 17:37).
Anointed as king, David served the reigning king Saul with humility and he did not attempt to take the kingdom by force, as he held him in high honour (1 Sm 24:6). King David did not conduct himself with integrity when he committed adultery and murder, but still had a repentant heart and was forgiven (Cafferky 2010:41).

Servant leadership principles defining the leadership of David are the following: honouring the name of God and trusting God in the face of overwhelming danger; submission and faithful service to a person in a ruling position; and confession and repentance of one's sins before God. Faith and trust in God, courage, vision, humility and repentance for one's sins are characteristics clearly associated with a servant leader.

\section{Paul}

Scripture portrays Paul as a persecutor of believers before he became an apostle of the Lord by grace, a title he carried with authority. He consistently referred to himself by this designation in his letters (see Rm 1:1; 1 Cor 1:1; Eph 1:1) and people widely recognised him as such (Tyson 2016:387). Paul followed a shared leadership style - one of the characteristics of servant leadership identified by Laub (1999). He worked with acquaintances on his missions, Priscilla, Aquila and Urbanus also reffered to as co-workers (Rm 13:3), and Titus, stated as his partner (2 Cor 8:23). Paul used foresight by getting Timothy circumcised because of the challenges they would face (Hoehl 2011:36). Paul empowered Timothy and prepared him for ministry and to deal with doctrinal errors and interpretation of scripture (Hoehl 2011:39), and then stepped back and allowed the young man to fulfill his role. Applauding noble leadership in others is a reflection of authenticity, being content with one's own capabilities and abilities and acknowledging what others have to offer.

Servant leadership principles standing out in the leadership of Paul are an awareness of authority based on divine appointment in the service of God, vision and commitment, dedication in spreading the Good News, shared leadership style, overseeing Scripture interpretation, and training and commending a successor. Personal characteristics are love for co-workers and fellow-believers, selflessness in stepping back when necessary and endurance in suffering because of the gospel.

\section{Jesus Christ}

Jesus is the embodiment of servant leadership. The concept befits Him in His teachings and the things He did by serving and leading. Jesus chose disciples that He would teach and empower to continue His ministry after His departure, that is shared leadership. Jesus gave the disciples authority to do what He was doing, going around, preaching the Good News and healing the sick (Troftgruben 2013:392). The disciples were active participants in the ministry of Jesus, they were not bystanders, but they learnt to do what $\mathrm{He}$ was doing. Jesus gave his disciples power (Greek dunamis, 
meaning 'ability') and authority (Greek exousia, meaning 'the right to exercise power'). Jesus did not just send the disciples, He gave them power and authority, that was important for the disciples to enable them to perform miracles to validate their preaching (Constable 2017b:144). Jesus made His mission clear by referring to Isaiah 61:1-2 (Constable 2017b:309). Jesus came and became a servant, even to the point of washing the feet of His disciples (Mt 20:28; Lk 22:27; Jn 13:14). The act of washing the disciples' feet was viewed as an act of supremacy; the one who received the washing was generally superior to the one doing the act (Åkerlund 2015:7). The word for 'servant' used in John 13 is the Greek diakon, which means 'one who serves in a lowly way'. Constable (2017b:323) states, 'what was not below their Master should not be below His servants'. Jesus was humble, though He had authority and power (Foster 1971:338).

Jesus demonstrated understanding, far-sightedness and watchfulness to the will of the Father. In His actions, Jesus did the will of the Father, showing unity and obedience (Jn 5:30). The Holy Spirit anointed Jesus when He was baptised, thereafter He started His ministry (Johnson 2017:148). Jesus was able to teach and do miracles under the leadership of and being empowered by the Holy Spirit (Constable 2017b:374). Jesus taught about integrity that people must practice what they teach. The authenticity and authority of one's teaching are reflected in how they conduct themselves with regard to what they teach (Troftgruben 2013:392). Throughout His ministry, Jesus related with all kinds of people, religious and sinners, going into crowded places and attending to those in need. Jesus acknowledged and affirmed Zacchaeus who saw himself as a sinner not worthy to host the Lord, and through this act, Jesus inspired change in Zacchaeus (Campolo \& Darling 2010:21). Jesus showed love and care to people who were condemned like the woman caught in adultery. Jesus brought healing to her soul through forgiveness not condemnation (Campolo \& Darling 2010:21). Jesus also reserved times for withdrawal, which is a time of solitude, where you are out of reach for a certain time (Blanchard 2003:88). Jesus spent time alone in preparation for the start of His ministry where He prayed and fasted (Mt 4:1-11).

Even such a cursory discussion as above confirms Jesus is the personification of servant leadership. All the principles indicated in the servant leadership of Moses, David and Paul are found in the leadership of Jesus. A few are preaching the Good News, giving priority to call workers for the kingdom of God, equipping them and giving them authority to continue the ministry, not only amongst their own people, but also in missionary work, fulfilling the will of the Father in complete obedience, withdrawing for reflection and prayer, serving in humility and not expecting to be served, love, compassion and sensitivity for the needs of people, involving other people in serving, enduring animosity and persecution, and suffering and sacrificing the self for the sake of others. Divine involvement is found in the fact that the Son of God Himself is the servant and the Holy Spirit is upon Him. To discuss all the characteristics of Jesus as a servant would be impossible within the scope of this article. Suffice to say that servanthood is inherent in the person of Jesus, as He revealed Himself in his teachings and actions on earth.

It is important that the content of the Bible should be contextualised for the existential needs in present times. When doing exegesis, a pericope should not only be read and understood in the context of the intended original readers, but the exegete also has to apply the principles to the current context. In pursuing the aim of contextualising the Biblical theme of servant leadership, some contemporary views of servant leadership will now be explored. If contemporary servant leader principles could be identified that are congruent with biblical principles, they could be used in a servant leadership model as part of spiritual formation of theological students.

\section{Servant leadership characteristics and competencies or skills}

Leadership is a practice whereby one influences others in a group to work towards realising an identified shared goal (Northouse 2013:5). The core of leadership is 'going out to show the way' (Greenleaf 2002:chap. 1). Leaders have a dream, a vision and all-encompassing purpose for which they lead others to work towards (Greenleaf 2002:chap. 1).

A servant leader is a servant first (Greenleaf 2002:chap. 1). He or she has the heart to serve people and then leadership is bestowed on them as a function or a role to play. The desire to serve inspires a servant leader to lead people. The servant nature is not conferred or presumed and cannot be taken away; it is the core of who the person is (Greenleaf 2002:chap. 1). Servanthood must be intrinsic in the leader's nature (Caldwell, McConkie \& Licona 2014:20). The fundamental principle of servant leadership is in the focus on other people before the leader considers their own issues (Chan \& So 2017:13). A servant leader is not just a servant who waits for instructions, but a leader who shows initiative, takes risks, assumes ownership, provides structure and is responsible for failures (Sousa \& Dierendonck 2017:14).

An important skill that students have to learn to be a servant leader is firstly the ability to listen and to understand. It is an attitude of seeking to understand, to hear what is said, to identify and clarify the will of others, to reflect on issues, to listen without being judgmental, to comprehend what causes a person to think and behave in a certain way, to view issues from the way another person sees, to clearly understand what is being communicated, and to get in touch with the inner voice that communicates matters of the body, mind and spirit (Campolo \& Darling 2010:70; Chan \& So 2017:15; Spears \& Lawrence 2004:chap. 2).

Important skills include the following: (1) language and imagination that enable open communication and 
information exchange to increase confidence and allegiance (Carroll \& Patterson 2014:19); (2) withdrawal when reaching one's optimum, which means stepping back from pressure at some point and identifying a point where one's abilities as a leader are optimally utilised and you have to reorient yourself and make choices that produce optimum performance (Greenleaf 2002:chap. 1); (3) acceptance and empathy, which implies having tolerance for others' imperfections (Greenleaf 2002:chap. 1); (4) foresight, which refers to the ability of a leader to review present issues and equate them with past events in order to make predictions for the future in the event of having nothing else for guidance (Greenleaf 2002:chap. 1); and (5) awareness and perception, which refers to an intense contact with, acute awareness of and creative insight into current situations (Greenleaf 2002:chap. 1), and qualities that enable the leader to view issues holistically whilst considering ethical consequences, power and values (Chan \& So 2017:15).

Persuasion, another skill of servant leadership, is the art of bringing about change by convincing rather than by coercing. In persuasion, the leader deals with one person at a time. He or she seeks to reach accord and to influence by model and partnership, a method that has a better chance of long-term success (Chan \& So 2017). Servant leadership is about the servant leader giving him or herself to people, a characteristic that naturally draws people towards him or her, thus effecting a change of heart in other people (Roach 2015:chap. 1). People are attracted through influence and not authority based on a position (Roach 2015:chap. 2). Persuasion asks for good conceptualisation as the ability to plot present matters and opportunities, articulating available prospects and using thorough reasoning based on a logical mental framework (Green et al. 2015:82). Community building is an important part of the task of a servant leader. It may include caring for orphans, those who are in jail, those who are sick, the education system and elderly (Greenleaf 2002:chap. 1). It therefore also involves healing and serving because both the leader and the follower have a need of wholeness, and whilst the leader is serving, they are also healed (Greenleaf 2002:chap. 1).

From the review of contemporary literature, several principles of servant leadership have been identified that are congruent with the biblical principles of servant leadership identified earlier. This creates the possibility of contextualising the biblical principles in the context of a contemporary curriculum for theological training. In the section 'Proposed servant leadership model', the information from contemporary literature will be presented systematically with a view to suggest a servant leadership model.

\section{Proposed servant leadership model}

Distinguishing and understanding the following five aspects of servant leadership will enable students to form a clear vision of servant leadership:
- Style: Leadership styles are the approaches or methods adopted and used by a leader to inspire and influence others towards a particular end goal (Uzohue, Yaja \& Akintayo 2016:20). Leadership style is a description of what the leader emphasises when they lead people (Mwenje 2015:56). Leadership styles are demonstrated in the manner in which a leader deals with people and work at hand, and it differs depending on the situation at hand (Uzohue et al. 2016:20). There are various leadership styles that leaders employ, such as transformational, transactional, participative, servant leadership and dictatorship styles. A description of all the various leadership styles should be included in the curriculum for the student to understand the differences in approach.

- Principles: Servant leadership should share responsibilities and promote healthy relationships. With the proposed model, the authors want to link with Laub's (1999) six principles of a servant leader, namely valuing people, developing people, building communities, displaying authenticity, providing leadership and sharing leadership.

- Functions: A pastor has to fulfill a specific role in the church and it involves distinct functions. These functions flow naturally from their character and competency. Some of these functions are setting, translating and executing a vision; providing and sharing leadership with the church members; becoming a role model and ambassador not only for adults but also for the youth and children in the church; identifying spiritual gifts and talents of the church members and helping them to grow and develop their gifts and talents; and continuously monitoring and improving the status quo.

- Character: The proposed model follows Spears and Lawrence (2004:27), who identified 10 characteristics of a servant leader, namely listening, empathy, healing, awareness, persuasion, conceptualisation, foresight, stewardship, commitment to the growth of people and community building.

- Competency: The servant leader's competency is seen in aspects like being a visionary, empowering others, showing stewardship skills and having a heart for other people in order to build relationships.

Nkambule (2019:222) proposes the servant leadership model in Figure 1.

In the proposed model, all the necessary aspects are given in an encompassing manner. The principles of servant leadership form the foundation of the model, whilst the importance of certain leadership styles, characteristics, competencies and the functions of a servant leader are highlighted.

From the biblical principles of servant leadership, the characteristics and skills of the biblical servant leader and the principles from contemporary literature, it is clear that the concept of servant leadership is noble; therefore, instruction in servant leadership should be 


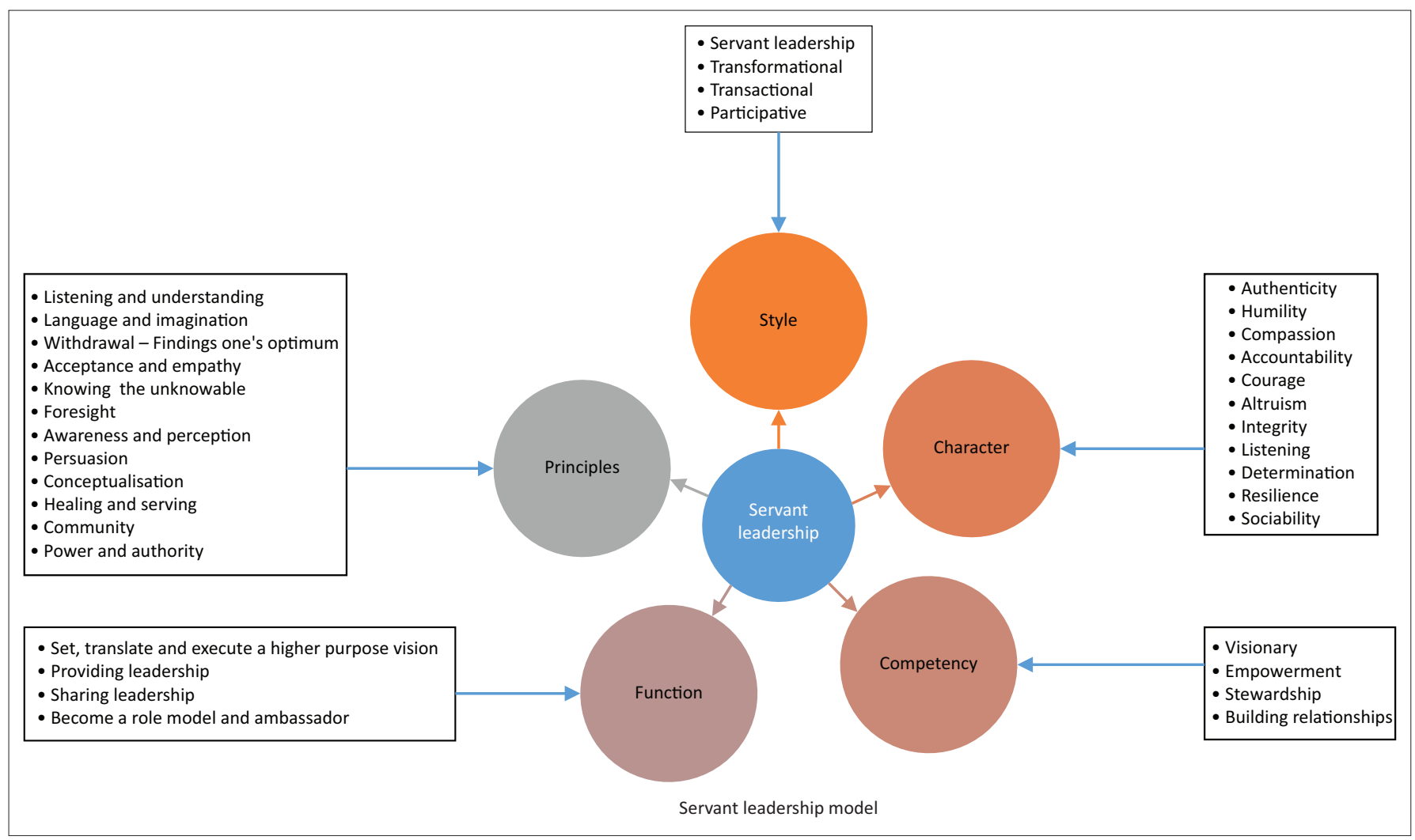

Source: Nkambule, C.M., 2019, 'The servant leadership paradigm of Jesus Christ applied in a current pastoral context', PhD thesis, North-West University, Potchefstroom. FIGURE 1: Servant leadership model.

included in the theological curriculum as part of the spiritual formation of students.

\section{Conclusion}

The principle of servant leadership is an example of the necessity of contextualising a biblical theme. A thorough understanding of a theme like servant leadership contributes to spiritual formation of theological students and will ultimately empower them to minister the Word of God, which means following in the footsteps of leaders such as Moses, David, Paul and Jesus Christ. Christians can draw inspiration from the historical record in the Bible where leaders are called 'servants'. They can do it with the knowledge that faith in Jesus Christ assures them that they are called by God himself to be servants for the benefit of others.

Jesus set the bar very high for leaders, which is sometimes difficult to attain. However, if theological students are committed and have faith that it is possible to attain the standard, then they will strive towards fulfilling their call. With this article, the authors aimed to propose a servant leadership model that could be integrated into the curriculum of theological students in an attempt to help them with their spiritual formation. In understanding and following a servant leadership model in ministry, the negative publicity surrounding the church in South Africa in the media might end. The two aspects of the term servant leadership and the way a balance can be found between the aspects have been discussed. The servant leadership examples of two Old Testament and two New Testament leaders have been identified. The article has been concluded with a proposal of a model as a summary of the research and that can be helpful for spiritual formation of students.

\section{Acknowledgements Competing interests}

The authors declare that they have no financial or personal relationships that may have inappropriately influenced them in writing this research article.

\section{Authors' contributions}

A.L.D.P. and C.M.N. contributed equally to this research article.

\section{Funding information}

This research received no specific grant from any funding agency in the public, commercial or not-for-profit sectors.

\section{Data availability statement}

Data sharing is not applicable to this article as no new data were created or analysed in this study.

\section{Disclaimer}

The views and opinions expressed in this article are those of the authors and do not necessarily reflect the official policy or position of any affiliated agency of the authors. 


\section{References}

Åkerlund, T., 2015, 'Son, sent, and servant: Johannine perspectives on leadership theory', Scandinavian Journal of Leadership and Theology 1(2), 1-16.

Ben-Hur, S. \& Jonsen, K., 2012, 'Ethical leadership: Lessons from Moses', Journal of Management Development 31(9), 962-973. https://doi.org/10.1108/ 02621711211259901

Blanchard, K., 2003, The servant leader: Transforming your heart, head, hands and habits, Thomas Nelson, Nashville, TN.

Cafferky, M.E., 2010, 'Honor the king, yes, but emulate the king?', The Journal of Applied Christian Leadership 4(2), 32-51.

Caldwell, C., McConkie, M. \& Licona, B., 2014, 'Simon Peter and transformative leadership: Leadership insights for today's leaders', Journal of Management and Strategy 5(1), 18-32. https://doi.org/10.5430/jms.v5n1p18

Campolo, A. \& Darling, M.A., 2010, Connecting like Jesus, Jossey-Bass, San Francisco, CA.

Carroll, B.C. \& Patterson, K., 2014, 'Servant leadership: A cross-cultural study between India and the United States', Servant Leadership Theory and Practice 1(1), 16-45.

Chan, K.W.C. \& So, G.B.K., 2017, 'Cultivating servant leaders in secondary schooling', Servant Leadership Theory \& Practice 4(1), 12-31.

Commission for the Promotion and Protection of the Rights of Cultural, Religious and Linguistic Communities, 2016, Preliminary report of the hearings on commercialisation of religion and abuse of people's belief systems, CR083/2016, CRL Rights Commission, Government Printers, Pretoria.

Constable, T.L., 2017a, Dr Constable's notes on Exodus, Sonic Light, Dallas, TX.

Constable, T.L., 2017b, Dr Constable's notes on Luke, Sonic Light, Dallas, TX.

Foster, R.C., 1971, Studies in the life of Christ, Baker Book House, Springfield, MO.

Green, M.T., Rodriguez, R.A., Wheeler, C.A. \& Baggerly-Hinijosa, B., 2015, 'Servant leadership: A quantitative review of instruments and related findings', Servant Leadership: Theory and Practice 2(2), 76-96.

Greenleaf, R.K., 2002, Servant leadership: A journey into the nature of legitimate power and greatness, Paulist Press, Mahwah, NJ.

Hays, R., 2012, 'Learning leadership from Moses: A biblical model for the church today', in H. Moffitt (ed.), Divinity, vol. 12, no. 1, pp. 5-9, Duke University, Durham.

Hoehl, S.E., 2011, 'The mentor relationship: An exploration of Paul as loving mentor to Timothy and the application of this relationship to contemporary leadership challenges', Journal of Biblical Perspectives in Leadership 3(2), 32-47.
Johnson, K., 2017, 'The work of the Holy Spirit in the ministry of Jesus Christ: A Trinitarian perspective', Trinity Journal 38(2), 147-167.

Kislev, I., 2009, 'The investiture of Joshua (Numbers 27:12-23) and the dispute on the form of leadership in Yehud', Vetus Testamentum 59(3), 429-445. https://doi. org/10.1163/156853309X436313

Laub, J.A., 1999, 'Assessing the servant organization: Development of the servant organizational leadership assessment (SOLA) instrument', PhD thesis, Florida Atlantic University.

Lipman-Blumen, J., 2005, The allure of toxic leaders, Oxford University Press, New York, NY.

Mokhoathi, J. \& Rembe, N.S., 2017, 'Religious liberties and the constitution of South Africa: A call for religious accountability', Scriptura 116(1), 1-10.

Mwenje, J., 2015, 'An investigation of the leadership styles of Pentecostal church leaders in Zimbabwe', African Journal of Business Management 10(3), 55-74. https://doi.org/10.5897/AJBM2015.7882

Nkambule, C.M., 2019, 'The servant leadership paradigm of Jesus Christ applied in a current pastoral context', PhD thesis, North-West University.

Northouse, N.G., 2013, Leadership theory and practice, 6th edn., Sage, Thousand Oaks, CA.

Roach, D., 2015, The servant leadership style of Jesus: A biblical strategy for leadership development, WestBow Press, Grand Rapids, MI.

Serrano, C., 2015, 'Charismatic and servant leadership as seen in King Saul and young David: An inner texture analysis of 1 Samuel 17:1-58', Journal of Biblical Perspectives in Leadership 6(1), 27-40.

Sousa, M. \& Van Dierendonck, D., 2017, 'Servant leadership and the effect of the interaction between humility, action and hierarchical power on follower engagement', Journal of Business Ethics 1(141), 13-25. https://doi.org/10.1007/ s10551-015-2725-y

Spears, L.C. \& Lawrence, M., 2004, Practicing servant leadership: Succeeding through trust, bravery and forgiveness, Wiley, San Francisco, CA.

Troftgruben, T.M., 2013, 'Lessons for teaching from the teacher: Matthew's Jesus on teaching and leading today', Currents in Theology and Mission 40(6), 387-398.

Tyson, J.B., 2016, 'Acts and the apostles: Issues of leadership in the second century', Perspectives in Religious Studies 43(4), 385-398.

Uzohue, C.E., Yaya, J.A. \& Akintayo, O.A., 2016, 'A review of leadership theories, principles, styles and their relevance to management of health science libraries in Nigeria', Journal of Educational Leadership and Policy 1(1), 17-26. 